\title{
PERILAKU KEPEMIMPINAN KEPALA MADRASAH TSANAWIYAH NEGERI
}

\author{
Oleh: \\ Ipong Dekawati \\ Universitas Wiralodra \\ (E-mail: ipongdekawati@unwir.ac.id)
}

\begin{abstract}
ABSTRAK
Tujuan penelitian ini adalah untuk mengetahui pentingnya seorang kepala madrasah sebagai salah satu penentu keberhasilan operasional madrasah, maka fokus penelitian ini berkaitan dengan perilaku kepemimpinan kepala madrasah tsanawiyah negeri pada salah satu Kabupaten di Provinsi Jawa barat. Metode untuk menganalisis penelitian ini dilaksanakan secara deskriptif dan verifikatif. Untuk mengumpulkan data dilakukan melalui studi dokumentasi, observasi, wawancara dan angket terhadap guru madrasah tsanawiyah negeri. Data hasil penelitian dianalisis secara tabulasi silang dengan memaknai persentase masing-masing dimensi perilaku kepemimpinan. Keberhasilan sekolah dalam menghasilkan output yang bagus dimulai dari kepemimpinan yang efektif dalam hal mana kepemimpinan efektif diawali dengan perilaku kepemimpinan yang baik. Perilaku kepemimpinan yang baik dalam mendorong peningkatan kualitas madrasah secara keseluruhan serta memberikan penghargaan kepada guru dan tenaga kependidikan lainnya yang berprestasi.
\end{abstract}

Kata Kunci: Kualitas Madrasah, Perilaku Kepemiminan Kepala Madrasah, Prestasi Guru dan Tenaga Kependidikan

\section{ABSTRACT}

The purpose of this study was to find out the importance of a madrasa head as one of the determinants of the operational success of madrasas, so the focus of this study relates to the leadership behavior of the head of the state madrasah tsanawiyah in one district in West Java Province. The method for analyzing this research was carried out descriptively and verificatively. To collect data, it was carried out through documentation studies, observations, interviews and questionnaires on the teachers of the state madrasah tsanawiyah. Data from the research results were analyzed by cross tabulation by interpreting the percentage of each dimension of leadership behavior. The success of schools in producing good output starts from effective leadership in which effective leadership begins with good leadership behavior. Good leadership behavior in encouraging the improvement of the quality of the madrasa as a whole and giving awards to teachers and other staff who excel.

Keywords: Madrasa Principal Leadership Behavior, Madrasa Quality, Teachers Achievement and Staff

\section{PENDAHULUAN}

Merupakan kesepakatan bahwa organisasi merupakan suatu kendaraan atau wadah untuk mencapai tujuan. Demikian halnya dengan madrasah tsanawiyah yang dikategorikan sama dengan sekolah menengah pertama dengan penambahan bobot pelajaran agama Islam. Selain sebagai kelanjutan periode wajib belajar, madrasah juga merupakan satuan pendidikan yang menjadi fondasi peserta didik untuk menjalani pendidikan tingkat atas. Oleh karenanya, operasional madrasah sangat esensial keberadaan dan eksistensinya. Fakta telah membuktikan bahwa peserta didik yang sukses mengikuti kegiatan pembelajaran pada pendidikan lanjutan merupakan alumni satuan pendidikan sebelumnya yang bermutu.

Sarana pendidikan, sumber daya manusia, material, anggaran biaya, iklim dan budaya organisasi serta perilaku kepemimpinan kepala madrasah merupakan faktor yang menentukan dalam suksesnya pengelolaan satuan pendidikan setingkat madrasah tsanawiyah sebagaimana yang diharapkan. Perilaku kepemimpinan kepala madrasah merupakan faktor dominan, maka seyogyanya kepala madrasah memiliki pengetahuan dan keterampilan yang memadai. Kepala madrasah juga dituntut memiliki kemampuan mengenal watak pegawai, menguasai teknik memberikan perintah, memberikan teguran, 
memberikan anjuran, memberikan pengertian, memperoleh saran, memberikan semangat yang dipimpin serta menanamkan rasa disiplin. Kepala madrasah harus mampu menggerakkan guru sedemikian rupa sehingga mereka mau memberikan pengabdian dan sumbangsihnya terutama dalam cara bekerja yang efektif, efisien dan produktif. Lebih dari itu kepala madrasah dituntut berperilaku layaknya seorang pemimpin yang menjadi sumber tauladan bagi guru, pegawai dan peserta didik. Sehingga perilaku kepemimpinan seorang kepala madrasah yang bagus merupakan suatu keniscayaan.

Pemimpin dan kepala madrasah bagai dua sisi mata uang, nyaris tidak bisa dipisahkan. Memiliki pengertian masing-masing tetapi di antara keduanya terdapat persamaan serta perbedaan. Persamaannya adalah keduanya mengelola atau mengepalai sebuah kelompok individu, dan keduanya saling mempunyai tanggungjawab yang penuh. Sedangkan perbedaannya kalau ditelaah secara seksama adalah: (1) Kepala madrasah bertindak sebagai penguasa, sedangkan seorang pemimpin hanya sebagai seorang organisator dan koordinator saja.

(2) Kepala madrasah bertanggung jawab kepada pihak ketiga, secara vertikal kepada pihak Kementerian Agama, sedangkan pemimpin bertangung jawab terhadap kelompok yang dipimpinnya. (3) Kepala madrasah tidaklah selalu menjadi bagian dari kelompok, sedangkan seorang pemimpin $\neg$ merupakan bagian yang integral dari kelompok. (4) Kekuasaan kepala madrasah, berasal dari peraturan peraturan atau dari pihak lain, namun bagi seorang pemimpin, berasal dari sebuah kepercayaan anggota/kelompoknya. (5) Kelompok/anak buah atau anggota, bukan atas kemauan sendiri, melainkan ditunjuk peraturan peraturan (karena adanya pengangkatan seorang kepala madrasah dari pihak lain).

Kepala madrasah adalah seorang kepala sebuah kelembagaan formal dari intitusi pendidikan. Oleh karena itu, kepala madrasah dikatakan pejabat formal (formal leadership), sekaligus merupakan kepemimpinan informal (informal leadership). Pemimpin formal adalah orang yang oleh organisasi atau institusinya diakui sebagai pemimpin berdasarkan keputusan dan pengangkatan resmi suatu jabatan dalam struktur organisasi, dengan segala hak dan kewajiban berkaitan dengannya, untuk mencapai tujuan dan sasaran organisasi” (Kartini Kartono, 2002). Kepala madrasah merupakan jabatan pemimpin yang memenuhi kriteria tertentu, seperti dilihat dari latar belakang pendidikan, pengalaman, masa kerja, kompetensi, usia, dan kecukupan jenjang karier. Kriteria, prosedur dan peraturan peraturan yang berlaku untuk pengangkatan seorang kepala madrasah tersebut dirancang oleh suatu unit yang bertangung jawab dalam bidang sumber daya manusia. Dalam prosesnya bidang sumberdaya manusia dimaksud bekerja sama dengan unit unit dan bidang lainnya untuk mendapatkan pemimpin madrasah yang paling tepat sesuai kriteria dan kebutuhan institusi kini dan masa yang akan datang.

Kepala madrasah menjadi manajemen puncak dari sebuah satuan pendidikan. Sebelum menjadi kepala madrasah ia adalah seorang guru, yang tadinya tanggung jawabnya terbatas hanya terhadap siswa yang diajarnya, tetapi setelah ia dipilih menjadi kepala madrasah, tanggung jawabnya meluas kepada para dewan guru dan peserta didik serta seluruh perangkat madrasah yang diserahkan dibawah pengawasan, bimbingan dan binaannya. Berhasil atau tidaknya sebuah madrasah dari segi peningkatan kualitas dan 
produktivitas guru, peningkatan mutu (output) pendidikan, tergantung pada kompetensi manajemen dan perilaku kepemimpinan seorang kepala madrasah.

Kepala madrasah merupakan figur yang paling menentukan dalam perkembangan semua aspek kehidupan madrasah, efektivitas dan efisiensi penegelolaan madrasah, menggerakkan (memobilisasi) berbagai unsur yang ada secara internal seperti, personil (bawahan), sarana dan prasarana, pendanaan, dan sebagainya, di lain pihak secara eksternal dapat pula berinteraksi dengan lembaga atau instansi lain sebagai mitra keja baik vertikal maupun horizontal termasuk masyarakat lingkungan sebagai pengguna institusi madrasah.

Peranan kepala madrasah dalam meningkatkan sumber daya manusia yang berkemampuan profesional seperti tenaga pendidik yang ada (guru), menjadi prioritas utama dalam menjabarkan kurikulum madrasah tsanawiyah untuk memperoleh output pendidikan yang maksimal. Sehubungan dengan hal itu, kompetensi kepala madrasah sangat dituntut berkreasi dan berinovasi dalam perencanaan pengorganisasian, pengarahan pemberian motivasi, pelaksanaan, pengkoordinasian dan evaluasi serta pengelolaan lingkungan kerja yang disiplin, harmonis dan kondusif. Peranan kepala madrasah tsanawiyah dengan sejumlah prinsip dapat menjadi keteguhan dan merupakan esensi prioritas dalam menjalankan misi dan visi madrasah. Langkah awal berpegang pada prinsip manajerial dan prinsip kepeminipinan, karena kepala madrasah adalah seorang manajer yang melaksanakan proses manajemen madrasah.

Madrasah sebagai suatu organisasi yang terbuka didalamnya terdapat unsur-unsur pendidikan juga akan sangat tergantung pada diri kemampuan kepala madrasah dalam menjalankan tugas kepemimpinannya. Menurut Robbins (2002:163) kepemimpian adalah kemampuan mempengaruhi suatu kelompok untuk mencapai tujuan. Kepemimpinan dipandang memiliki tingkat urgensi tinggi karena kenyataannya menunjukkan bahwa penggantian pemimpin acap mengubah kinerja suatu unit, instansi atau organisasi. Kemudian hasil penelitian juga menunjukkan bahwa salah satu faktor internal yang mempengaruhi keberhasilan organisasi adalah kepemimpinan yang mencakup proses kepemimpinan pada setiap jenjang organisasi, kompetensi dan tindakan pemimpin yang bersangkutan (Yukl, 1989). James Owen (1991) berkeyakinan bahwa perilaku dapat dipelajari. Oleh karena itu, orang yang dilatih tentang perilaku kepemimpinan yang tepat cenderung mampu memimpin secara efektif. Sekalipun demikian, perilaku kepemimpinan yang cocok dalam satu institusi atau situasi dan kondisi tertentu belum tentu cocok pada institusi, situasi dan kondisi yang lain. Robert F. Bales (Stoner dan Freeman, 2004) mengemukakan hasil penelitian, bahwa mayoritas kelompok yang efektif mempunyai bentuk kepemimpinan terbagi (shared leadership), misalnya saja, satu oramg melaksanakan fungsi tugas dan anggota lainnya melaksanakan fungsi sosial. Karena dengan berbagi fungsi akan lebih fokus di dalam melaksanakannya. Pendekatan perilaku ini lebih memfokuskan pada beberapa tindakan pemimpin, seperti bagaimana melakukan pendelegasian wewenang, berkomunikasi dengan orang-orang, membina dan memotivasi anggotanya. Atas dasar itulah para teoritisi memfokuskan pendekatan perilaku kepemimpinan pada dua aspek, yaitu fungsi-fungsi kepemimpinan (leadership functions) dan gaya kepemimpinan (leadership styles). 
Gross (Anwar dan Hidayat, 2000) mengklasifikasikan fungsi kepemimpinan pada aspek menentukan tujuan, menjelaskan, melaksanakan dan memilih cara yang tepat, memberikan motivasi serta merangsang para anggota untuk bekerja. Bartolak dari hal tersebut, seorang kepala madrasah harus dapat menentukan gaya kepemimpinannya serta harus dapat menentukan orientasi perilaku kepemimpinan. Artinya bahwa dalam menjalankan tugas kepemimpinannya seorang kepala madrasah dituntut berperilaku dengan kecenderungan pada gaya dan orientasi perilaku kepemimpinan tertentu. Kesuksesan kepala madrasah dalam pengelolaan satuan pendidikan sangat dipengaruhi oleh sikap dan gaya kepemimpinan yang dilakukan oleh kepala madrasah tersebut. Sikap dan gaya kepemimpinan itu tampak dalam kegiatannya sehari-hari, misalnya terlihat dari caranya memberikan perintah, membagi tugas dan kewenangan, mendorong semangat kerja para guru, memberi bimbingan dan pengawasan, menyelenggarakan dan memimpin rapat, membina disiplin kerja guru, cara mengambil putusan dan sebagainya.

Berbicara mengenai perilaku kepemimpinan, secara kognitif memiliki kontribusi bagi para praktisi sekalipun hanya melalui kerjasama antar individu dalam organisasi sebagaimana disampaikan Edina Dóci, Jeroen Stouten, dan Joeri Hofmans (2015), bahwa "only by incorporating intra-individual variation in leadership behavior into the scope of investigation, and by identifying the cognitive mechanisms that trigger favorable leadership behaviors, it is possible to offer relevant contributions for practitioners" atau hanya dengan variasi kerjasama intraindividual dalam perilaku kepemimpinan ke dalam lingkup penyelidikan, dan dengan mengidentifikasi mekanisme kognitif yang memicu perilaku kepemimpinan yang menguntungkan, adalah mungkin untuk menawarkan kontribusi yang relevan bagi praktisi. Tannenbaum dan Schmidt (Agus Dharma, 2000:108) menyampaikan bahwa "gaya kepemimpinan dapat dilukiskan sebagai suatu kontinum". Kontinum tersebut tersebar di antara dua gaya yang ekstrim, yaitu gaya kepemimpinan yang otokratis dan gaya kepemimpinan yang demokatis. Jika kontinum itu dapat diumpamakan sebagai suatu garis, maka pada ujung garis yang satu terletak gaya kepemimpinan otokratis dan pada ujung garis yang lain terletak gaya kepemimpinan yang demokatis. Masih menurut Tannenbaum dan Schmidt dalam Davis dan Newstrom terjemahan Agus Dharma (2000:184), mengutarakan bahwa 'kepemimpinan yang otokratis tekanan orientasinya diarahkan pada tugas atau tercapainya tujuan organisasi, sedangkan kepemimpinan demokatis titik berat orientasinya pada hubungan pemimpin dengan yang dipimpin'. Dengan demikian jika dilihat dari otoritas pemimpin di satu pihak dan kebebasan bawahan di pihak yang lain, maka makin otoriter seorang pemimpin, makin besar otoritasnya dan makin tidak ada kebebasan bagi bawahan. Begitu pula sebaliknya makin demokratis seorang pimpinan, maka makin besar kebebasan diberikan kepada bawahan. Gaya kepemimpinan yang diuraikan di atas, digambarkan pada ilustrasi sebagai berikut: 


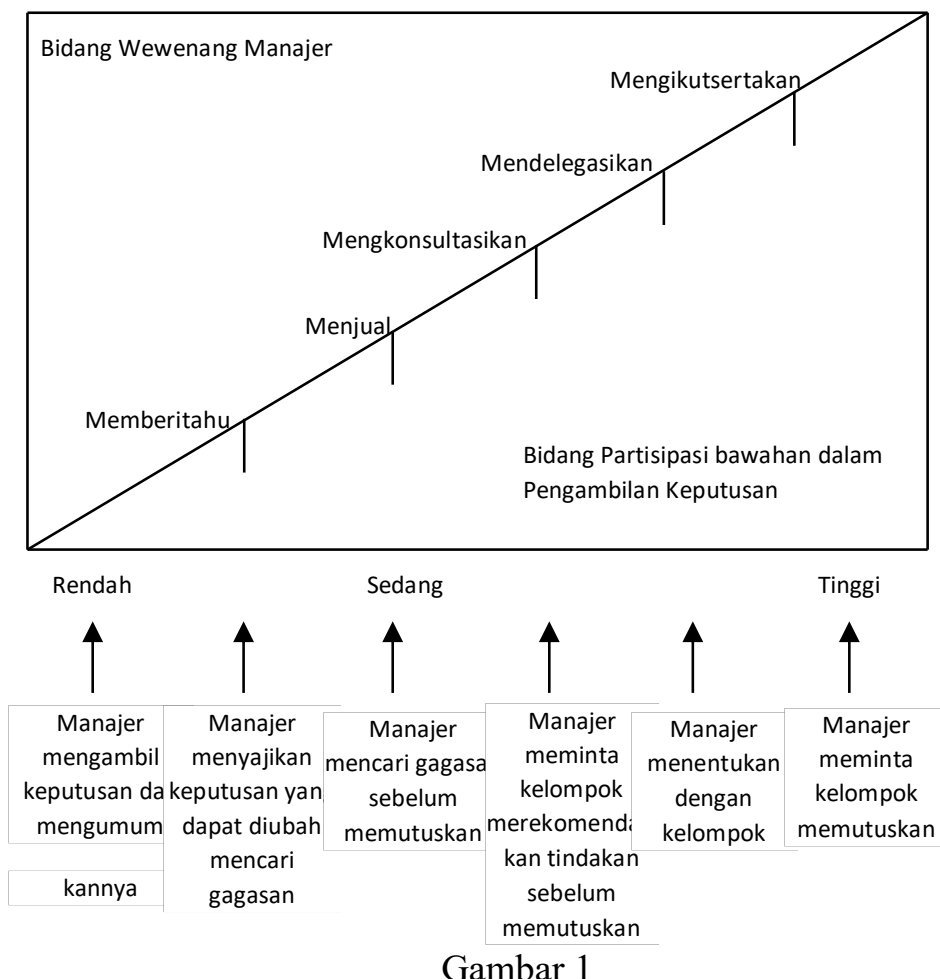

Kontinum Perilaku Kepemimpinan

Sumber: Robert Tannenbaum dan Warren $\mathrm{H}$ Schmidt (dalam Keith Davis dan John W. Newstrom Terjemahan Agus Dharma (2000:184)).

Sementara itu studi kepemimpinan Universitas Ohio tahun 1995 mengidentiflkasikan berbagai dimensi perilaku kepemimpinan: Pertama, perilaku kepemimpinan yang berorientasi pada tugas. Yaitu cara pemimpin melukiskan hubungannya dengan bawahan dalam usaha menetapkan pola organisasi, saluran komunikasi dan metode atau prosedur yang dipakai di dalam organisasi. Dengan karakteristik, sebagai berikut: (a) Mengutamakan tercapainya tujuan organisasi; (b) Mementingkan produksi yang tinggi; (c) Mengutamakan penyelesaian tugas menurut jadwal yang telah ditentukan. (d) Lebih banyak melakukan pengarahan; (e) Melaksanakan tugas dengan melalui prosedur kerja yang ketat; (f) Melakukan pengawan dengan ketat; (g) Penilaian terhadap bawahan semata-mata berdasarkan hasil kerja. Kedua, perilaku kepemimpinan yang berorientasi pada karyawan. Yaitu perilaku yang berhubungan dengan persahabatan, saling percaya, saling menghargai dan keintiman hubungan antara pemimpin dan bawahannya. Dengan karakteristik, sebagai berikut: (a) Memperhatikan kebutuan bawahan; (b) Berusaha menciptakan suasana saling percaya mempercayai; (c) Berusaha untuk menciptakan suasana saling harga menghargai; (d) Simpati terhadap bawahan; (e) Memiliki sikap bersahabat; (f) Menumbuhkan peran serta bawahan dalam pembuatan keputusan dan kegiatan lain; (g) Mengutamakan pengarahan diri, disiplin diri dan pengontrolan diri.

Menurut Ridwan El Hariri (2011), "pendekatan perilaku memandang bahwa kepemimpinan dapat dipelajari dari pola tingkah laku, dan bukan dari sifat-sifat (traits). Sorotan teori ini adalah tingkah laku para pemimpin pada saat mereka berupaya mempengaruhi para anggota kelompok, baik secara perseorangan maupun kolektif." Selanjutnya, masih menurut Hariri, bahwa "perilaku kepemimpinan merupakan tindakan-tindakan spesifik seorang pemimpin dalam mengarahkan dan mengkoordinasikan kerja anggota kelompok."

Perilaku kepemimpinan tersebut tidak saling bergantung. Artinya pelaksanaan perilaku yang satu tidak mempengaruhi perilaku yang lain. Dengan demikian seorang pemimpin dapat sekaligus berperilaku kepemimpinan struktur tugas dan tenggang rasa dalam derajat yang sama-sama tinggi atau sama-sama rendah. Selanjutnya dalam organisasi yang dipimpin dengan perilaku struktur tugas, prestasi kerja para pegawai baik, tetapi banyak absensi dan keluhan sedikit. Dan jika kedua perilaku tersebut diterapkan sekaligus dengan derajat yang sama-sama tinggi, maka produkivitas dan kepuasan kerja cenderung meningkat.

Dengan mengetahui berbagai gaya kepemimpinan, diharapkan para kepala madrasah 
dapat memilih dan menerapkan perilaku kepemimpinan mana yang dipandang paling efektif berdasarkan sifat-sifat, perilaku kelompok, dan kondisi serta situasi lembaga yang dipimpinnya. Kepala madrasah sebagai pemimpin juga harus peka terhadap situasi yang terjadi di dalam lingkungan interen madrasah maupun dalam lingkungan luar madrasah. Hal ini perlu karena suasana yang mewarnai kehidupan madrasah banyak ditentukan oleh kepekaan kepala madrasah dalam menghadapi situasi yang terjadi di madrasah.

Dalam melaksanakan kepemimpinannya, kepala madrasah secara garis besar cenderung sama. Sekalipun terdapat perbedaan semata-mata disebabkan oleh: (1) Keahlian dan pengetahuan kepala madrasah untuk menjalankan kepemimpinannya. Misalnya menyangkut latar belakang pendididikan atau ijazah yang dimilikinya, sesuai tidaknya latar belakang pendidikan itu dengan tugasnya sebagai pemimpin yang menjadi tanggung jawabnya, pengalaman kerja sebagai pemimpin. (2) Madrasah tempat kepala madrasah melaksanakan tugas jabatannya. Perilaku dan sikap seorang pemimpin lembaga yang tidak sejenis memiliki tujuan yang berbeda dan menuntut cara-cara pencapaian tujuan yang tidak sama. Oleh karena itu, tiap jenis lembaga memerlukan perilaku dan sikap kepemimpinan yang berbeda pula. (3) Sifat-sifat kepribadian pemimpin. Adanya perbedaan-perbeadaan watak dan keperibadian yang dimiliki oleh masingmasing pemimpin meskipun beberapa orang pemimpin memiliki latar belakang pendidikan yang sama dan diserahi tugas memimpin lembagalembaga yang sejenis, karena perbedaan kepribadian akan menimbulkan perilaku dan sikap yang berbeda pula dalam menjalankan kepemimpinannya. (4) Sifat-sifat keperibadian guru selaku kelompok yang didampinginya. Seorang kepala madrasah yang memimpin guruguru berpendidikan strata 1, akan bersikap dan berperilaku tidak sama dengan kepala madrasah yang mempunyai guru-guru yang berpendidikan lebih rendah atau lebih tinggi; (5) Sanksi-sanksi yang diterapkan kepala madrasah. Kekuatankekuatan yang ada di belakang kepala madrasah menentukan sikap dan tingkah lakunya. Sikap guru dan tenaga kependidikan lainnya dari seorang kepala madrasah yang mempunyai wewenang penuh akan berbeda jika dibandingkan dengan sikap anggota guru dan tenaga kependidikan dari seorang pemimpin yang kurang berwenang. Seorang guru yang baru ditunjuk sebagai pejabat kepala madrasah akan bertindak dan berperilaku berbeda jika dibandingkan dengan seseorang kepala madrasah yang telah resmi diangkat dengan surat keputusan dari atasan.

Dari paparan di atas dapat disarikan, bahwa: (1) Kepemimpinan merupakan serangkaian kemampuan dan sifat-sifat keperibadian serta kewibawaan sebagai sarana dalam rangka meyakinkan yang dipimpin agar mereka mau dan dapat melaksanakan tugas-tugas yang dibebankan kepadanya dengan rela, penuh semangat, ada kegembiraan batin, serta merasa tidak terpaksa. (2) Perilaku kepemimpinan ditandai oleh adanya kemauan merintis perbuatan kelompok yang produktif ke arah tujuan-tujuan yang dapat diterima dan kemampuan memelihara hubungan, kerjasama dan komitmen kelompok.

Perilaku kepemimpinan dalam perspektif islam didasarkan pada sikap Nabi Muhammad SAW. dalam memimpin umatnya. Pada masanya, Rasulullah SAW. menyelesaikan setiap masalah tanpa kekerasan dan pemaksaan. Rasulullah menerapkan akhlakul karimah dalam berperilaku memimpin. Oleh karenanya, Rasulullah 
merupakan figur teladan sebagaimana tertulis dalam Al-Qur'an surat Al-Ahzab, 33: 21 yang berbunyi: "Sesungguhnya telah ada pada (diri) Rasulullah itu suri teladan yang baik bagimu (yaitu) bagi orang yang mengharap (rahmat) Allah dan (kedatangan) hari kiamat dan yang banyak mengingat Allah."

Stategi Rasulullah dalam memimpin umat, di antaranya: Pertama, kualitas moral-personal prima yang disederhanakan, menjadi empat sebagai sifat wajib bagi rasul, yakni: siddiq, amanah, tabligh, fathonah. Kedua, intergritas. Integritas juga menjadi bagian penting dari kepribadian rasulullah yang telah membuatnya berhasil dalam mencapai tujuan risalahnya. Integritas personalnya sedemikian kuat sehingga tak ada yang bisa mengalihkannya dari apapun yang menjadi tujuanya. Ketiga, kesamaan di depan hukum. Prinsip keselarasan di depan hukum merupakan salah satu dasa penting. Keempat, penerapan pola hubungan egaliter dan akrab. Salah satu fakta menarik tentang nilai-nilai manajerial kepemimpinan rasulullah adalah penggunaan konsep sahabat (bukan murid, staff, pembantu, anak buah, anggota, rakyat, atau hamba) untuk menggambarkan pola hubungan antara beliau sebagai pemimpin dengan orang-orang yang berada dibawah kepemimpinannya. Kelima, kecakapan membaca kondisi dan merancang strategi. Keberhasilan Rasulullah sebagai seorang pemimpin tak lepas dari kecakapannya membaca situasi dan kondisi yang dihadapinya serta merancang strategi yang sesuai untuk diterapkan. Keenam, tidak mengambil kesempatan dari kedudukan. Rasulullah SAW. wafat tanpa meninggalkan warisan material. Sebuah riwayat menyatakan bahwa beliau berdo'a untuk mati dan bangkit di akhirat bersama orang-orang miskin. Sikap inilah yang membuat para sahabat rela memberikan semuanya untuk perjuangan tanpa peduli dengan kekayaannya, sebab mereka tidak pernah melihat rasulullah mencoba memperkaya diri. Ketujuh, visioner futuristic. Sejumlah hadits menunjukkan bahwa rasulullah adalah seorang pemimpin yang visioner, berfikir demi masa depan (suistinable). Kedelapan, menjadi prototipe bagi seluruh prinsip dan ajarannya pribadi rasulullah benar-benar mengandung cita-cita dan sekaligus proses panjang upaya pencapaian cita-cita tersebut. Beliau adalah personifikasi dari misisnya. Rasulullah selalu menjadi contoh bagi apapun yang ia anjurkan kepada orang-orang disekitarnya (www.pusatalquran.com, 2014).

Bertolak dari paparan di atas, maka bagi seorang pemimpin perlu menyesuaikan perilaku kepemimpinan yang diterapkan atas dasar kekuatan-kekuatannya yang ada pada dirinya dan bawahannya pada situasi yang tepat. Untuk mengatasi ketidaktepatan perilaku kepemimpinan, kepala sekolah sebagai pemimpin pendidikan harus mempunyai kemampuan-kemampuan yang menggambarkan tugas dan peranan kepala madrasah dalam penerapan kepemimpinan pendidikan. Adapun indikatornya terdiri dari: (a) Kemampuan menyusun rencana dan menetapkan strategi; (b) Kemampuan mengelola personil; (c) Kemampuan mengambil keputusan; (d) Kemampuan menjalin komunikasi; (e) Kemampuan mengendalikan kegiatan operasional. (f) Kemampuan keteladanan.

\section{METODE PENELITIAN}

Metode penelitian yang digunakan dalam penelitian ini adalah metode deskriptif analisis, dengan menggunakan teknik survey kuesioner untuk menggambarkan suatu situasi pada populasi. 
Penelitian deskriptif juga merupakan penelitian yang mengumpulkan data untuk mengetes pertanyaan penelitian yang berkaitan dengan keadaan dan kejadian sekarang, dan melaporkan objek penelitian sesuai dengan apa adanya.

Populasinya adalah guru madrasah tsanawiyah negeri yang berjumlah 180 orang. Oleh karena strata responden sama yaitu guru, maka pengambilan sampel digunakan metode simple random sampling. Jumlah sampel yang diambil mengacu pada rumus Slovin, Yaitu $=64,28$ dibulatkan 64 Orang

Teknik pengumpulan data melalui studi literatur, dokumentasi, angket dan wawancara terstruktur. Data kemudian diolah dan dianalisis dengan cara tabulasi silang.

\section{HASIL PENELITIAN DAN PEMBAHASAN}

Berdasarkan data yang diperoleh dari penelitian yang telah dilaksanakan, terlihat bahwa tanggapan guru sebagai mitra kepala madrasah mengenai perilaku kepemimpinan kepala madrasah, adalah sebagai berikut.

Tabel 1. Kemampuan Menyusun Rencana dan Menetapkan Strategi.

\begin{tabular}{|c|c|c|c|}
\hline Dimensi & Indikator & $\begin{array}{c}\text { Rata- } \\
\text { rata } \\
\text { Jawaba } \\
\text { n }\end{array}$ & $\begin{array}{c}\text { Kondis } \\
\text { i }\end{array}$ \\
\hline $\begin{array}{l}\text { Kemampuan } \\
\text { Menyusun } \\
\text { Rencana dan } \\
\text { Menetapkan } \\
\text { Strategi }\end{array}$ & $\begin{array}{l}\text { Memahami } \\
\text { tujuan } \\
\text { Melaksanaka } \\
\text { n misi } \\
\text { Membuat } \\
\text { rencana kerja } \\
\text { Menetapkan } \\
\text { target hasil } \\
\text { kerja } \\
\text { Menyusun } \\
\text { kalender } \\
\text { akademik }\end{array}$ & 4.22 & $\begin{array}{l}\text { Sangat } \\
\text { Bagus } \\
\text { Sangat } \\
\text { Bagus } \\
\text { Sangat } \\
\text { Bagus } \\
\text { Sangat } \\
\text { Bagus } \\
\text { Sangat } \\
\text { Bagus }\end{array}$ \\
\hline
\end{tabular}

Pada Tabel 1 terlihat bahwa nilai indikator terendah dalam kemampuan menyusun rencana dan strategi adalah indikator menetapkan target hasil kerja. Kondisi demikian menggambarkan bahwa kepala madrasah masih kurang cermat dalam mengumpulkan data untuk keperluan penetapkan target sehingga prediksinya kurang akurat. Di sana juga tergambar bahwa secara umum kepala madrasah sangat memahami tujuan

madrasah itu sendiri. Namun demikian secara keseluruhan indikator memiliki nilai sangat baik dihadapan para guru.

Tabel 2. Kemampuan Mengelola Personil.

\begin{tabular}{|c|c|c|c|}
\hline Dimensi & Indikator & $\begin{array}{c}\text { Rata- } \\
\text { rata } \\
\text { Jawaban }\end{array}$ & Kondisi \\
\hline \multirow{8}{*}{$\begin{array}{l}\text { Kemampuan } \\
\text { Mengelola } \\
\text { Personil }\end{array}$} & Menetapkan & \multirow[t]{3}{*}{4.10} & Sangat \\
\hline & wewenang dan & & Bagus \\
\hline & tanggung jawab & & \\
\hline & Memberikan & \multirow[t]{2}{*}{4.28} & Sangat \\
\hline & $\begin{array}{l}\text { bimbingan dan } \\
\text { pengarahan }\end{array}$ & & Bagus \\
\hline & Kebebasan & \multirow[t]{2}{*}{4.30} & Sangat \\
\hline & $\begin{array}{l}\text { menyampaikan } \\
\text { pendapat }\end{array}$ & & Bagus \\
\hline & $\begin{array}{l}\text { Menghormati } \\
\text { pendapat guru }\end{array}$ & 4.14 & $\begin{array}{l}\text { Sangat } \\
\text { Bagus }\end{array}$ \\
\hline
\end{tabular}

terendah dalam kemampuan mengelola personil adalah mengenai penetapan wewenang dan tanggung jawab. Situasi ini memberikan informasi bahwa kepala madrasah masih belum optimal dalam menyampaikan atau menyosialisasikan uraian tugas dan tanggung jawab kepada guru dan pegawai lainnya. Nilai Indikator tertinggi pada dimensi ini adalah kebebasan menyampaikan pendapat. Maknanya bahwa kepala madrasah sangat menghargai ide dan ragam inspirasi dari guru untuk kemajuan madrasah. 
Tabel 3. Kemampuan Mengambil Keputusan.

\begin{tabular}{|c|c|c|c|}
\hline Dimensi & Indikator & $\begin{array}{c}\text { Rata- } \\
\text { rata } \\
\text { Jawaban }\end{array}$ & Kondisi \\
\hline \multirow{7}{*}{$\begin{array}{l}\text { Kemampuan } \\
\text { Mengambil } \\
\text { Keputusan }\end{array}$} & Mengambil & 3.58 & Bagus \\
\hline & keputusan & & \\
\hline & sewaktu & & \\
\hline & $\begin{array}{l}\text { Mengembangkan } \\
\text { suasana kerja } \\
\text { yang bersahabat }\end{array}$ & 3.62 & Bagus \\
\hline & Menghindari & 4.44 & Sangat \\
\hline & $\begin{array}{l}\text { kegiatan yang } \\
\text { tidak sesuai } \\
\text { peraturan }\end{array}$ & & Bagus \\
\hline & $\begin{array}{l}\text { Pendekatan tanpa } \\
\text { pemaksaaan }\end{array}$ & 3.87 & Bagus \\
\hline
\end{tabular}

Pada Tabel 3 terlihat bahwa nilai indikator terendah dalam kemampuan mengambil keputusan sewaktu. Untuk mengambil keputusan cepat pada situasi tertentu memang memerlukan kecerdasan yang tinggi serta pengalaman dan wawasan yang luas. Secara umum kepala madrasah memerlukan waktu yang cukup untuk menetapkan keputusan, sedangkan untuk mengambil keputusan sewaktu atau secara mendadak termasuk kurang cermat. Nilai indikator tertinggi pada dimensi ini adalah bahwa kepal madrasah sangat taat terhadap peraturan sehingga tidak mau melaksanakan kegiatan yang sifatnya melanggar peraturan. Berdasarkan skor yang didapat dari hasil penelitian menunjukkan bahwa perilaku kepala madrasah pada dimensi kemampuan mengambil keputusan termasuk kondisi biasa saja, tidak jelek dan tidak termasuk sangat bagus.

Tabel 4. Kemampuan Menjalin Komunikasi.

\begin{tabular}{|c|c|c|c|}
\hline Dimensi & Indikator & $\begin{array}{c}\text { Rata- } \\
\text { rata } \\
\text { Jawaban }\end{array}$ & Kondisi \\
\hline $\begin{array}{l}\text { Kemampuan } \\
\text { Menjalin }\end{array}$ & $\begin{array}{l}\text { Transparansi } \\
\text { informasi }\end{array}$ & 3.72 & Bagus \\
\hline \multirow[t]{3}{*}{ Komunikasi } & $\begin{array}{l}\text { Saling } \\
\text { menghargai }\end{array}$ & 3.88 & Bagus \\
\hline & $\begin{array}{l}\text { Kewenangan } \\
\text { urusan } \\
\text { pembelajaran }\end{array}$ & 4.20 & $\begin{array}{l}\text { Sangat } \\
\text { Bagus }\end{array}$ \\
\hline & $\begin{array}{l}\text { Intensitas } \\
\text { pertemuan }\end{array}$ & 3.64 & Bagus \\
\hline
\end{tabular}

Pada Tabel 4 terlihat bahwa nilai indikator terendah dalam kemampuan menjalin komunikasi adalah intensitas pertemuan yang disusul oleh kurang transparansinya informasi. Terdapat keterkaitan antara kurang frekuensi intensifnya pertemuan antara kepala dengan guru madrasah. Karena kurang intensitasnya pertemuan atau rapat antara kepala madrasah dengan guru sehingga tidak semua informasi secara lengkap kepada guru. Nilai indicator tertinggi pada dimensi ini adalah bahwa kepala sekolah memberikan kewenangan yang luas kepada guru dalam mengembangkan teknik dan metoda pembelajaran. Sehingga memungkinkan guru menyampaikan materi pelajaran secara dinamis sesuai perkembangan yang terjadi di masyarakat. Secara umum kepala madrasah masih lemah dalam kemampuan menjalin komunikasi.

Tabel 5. Kemampuan Mengendalikan Kegiatan

\begin{tabular}{|c|c|c|c|}
\hline Dimensi & Indikator & $\begin{array}{c}\text { Rata- } \\
\text { rata } \\
\text { Jawaba } \\
\text { n } \\
\end{array}$ & $\begin{array}{c}\text { Kondis } \\
\quad \text { i }\end{array}$ \\
\hline \multirow{4}{*}{$\begin{array}{l}\text { Kemampuan } \\
\text { Mengendalika } \\
\mathrm{n} \\
\text { Kegiatan } \\
\text { Operasional }\end{array}$} & $\begin{array}{l}\text { Pelaksanaan } \\
\text { supervisi } \\
\text { kelas }\end{array}$ & 3.90 & Bagus \\
\hline & $\begin{array}{l}\text { Pengawasan } \\
\text { tugas } \\
\text { administrasi } \\
\text { pembelajara } \\
\mathrm{n}\end{array}$ & 3.70 & Bagus \\
\hline & $\begin{array}{l}\text { Pemberian } \\
\text { teguran } \\
\text { kepada guru } \\
\text { yang lalai }\end{array}$ & 3.55 & Bagus \\
\hline & $\begin{array}{l}\text { Pujian pada } \\
\text { pekerjaan } \\
\text { yang bagus }\end{array}$ & 4.12 & $\begin{array}{l}\text { Sangat } \\
\text { Bagus }\end{array}$ \\
\hline
\end{tabular}

Pada Tabel 5 terlihat bahwa nilai indikator terendah dalam kemampuan mengendalikan kegiatan operasional adalah menyangkut pemberian teguran kepada guru yang lalai. Kondisi demikian menggambarkan bahwa kepala madrasah kurang keberanian untuk menegur dan meluruskan tindakan guru yang lalai. Pada sisi lain kepala sekolah acap memberikan pujian kepada guru yang 
kinerjanya bagus. Secara umum dapat dinyatakan bahwa kepala madrasah masih belum optimal dalam melaksanakan supervisi kelas dan supervisi administratif. Sehingga penilaian guru berkaitan dengan kemampuan mengendalikan kegiatan oiperasional masih belum sesuai harapan.

Tabel 6. Kemampuan Keteladanan.

\begin{tabular}{|c|c|c|c|}
\hline Dimensi & Indikator & $\begin{array}{l}\text { Rata- } \\
\text { rata } \\
\text { Jawaban }\end{array}$ & Kondisi \\
\hline \multirow{6}{*}{$\begin{array}{l}\text { Kemampuan } \\
\text { Keteladanan } \\
\text { Perilaku }\end{array}$} & Keteladanan & 4.52 & Sangat \\
\hline & ahlak & & Bagus \\
\hline & Keteladanan & 4.40 & Sangat \\
\hline & Keteladanan & 4.32 & Sangat \\
\hline & berperilaku & & Bagus \\
\hline & $\begin{array}{l}\text { Keteladanan } \\
\text { penampilan }\end{array}$ & 4.20 & $\begin{array}{l}\text { Sangat } \\
\text { Bagus }\end{array}$ \\
\hline
\end{tabular}

Pada Tabel 6 terlihat bahwa nilai indikator terendah mengenai kemampuan keteladanan dalam perilaku adalah menyangkut penampilan diri kepala madrasah pada waktu keseharian ketika bekerja. Hal ini menandakan bahwa kepala madrasah menjaga penampilannya sebagai seorang pemimpin pada satuan pendidikan relatif detail dimulai dari cara berpakaian hingga penampilan fisik secara keseluruhan. Nilai indikator tertinggi pada dimensi ini menyangkut ahlak. Kepala madrasah dianggap berahlak baik atau ahlakul karimah. Oleh karena itu, secara umum perilaku kepala madrasah dapat dijadikan suri tauladan bagi guru dan peserta didik.

\section{SIMPULAN DAN REKOMENDASI}

Dengan tidak bermaksud mengecilkan makna perilaku kepemimpinan kepala madrasah yang sudah dikategorikan sangat bagus. Dari analisis hasil penelitian dapat dimaknai bahwa perilaku kepala madrasah masih lemah dalam supervisi kelas dan supervisi administratif. Sementara itu, kepala sekolah kurang tegas dalam memberikan teguran kepada guru yang lalai. Kemampuan komunikasi tidak sampai secara tuntas kepada guru yang dimungkinkan karena sangat terbatasnya intensitas pertemuan guru dengan kepala madrasah.

Kualitas proses pendidikan di antaranya sangat ditentukan oleh bagaimana kepala madrasah dalam memimpin dan mengelola madrasah itu sendiri. Keberhasilan sekolah dalam menghasilkan output yang bagus dimulai dari kepemimpinan efektif. Kepemimpinan efektif diawali dengan perilaku kepemimpinan yang baik. Perilaku kepemimpinan yang baik dalam mendorong peningkatan kualitas madrasah secara keseluruhan dapat dimulai dengan meningkatkan pengawasan dan transparansi informasi, memberikan sanksi yang wajar terhadap guru dan atau tenaga kependidikan lainnya yang kinerjanya kurang baik, serta memberikan penghargaan kepada guru dan tenaga kependidikan lainnya yang berprestasi.

\section{DAFTAR PUSTAKA}

Agus Dharma. (2000), Gaya Kepemimpinan Yang Efektif Bagi Para Manajer, Bandung : Sinar Baru.

Anwar, Idochi dan Hidayat.Yayat. (2000), Administrasi Pendidikan, Teori Konsep dan Isu. Bandung : PPS, UPI.
Arikunto. Suharsimi. (2000), Prosedur Penelitian: Suatu Pendekatan Praktek. Jakarta: Rineka Cipta.

Atmodiwirio, Soebagio (2000), Manajemen Pendidikan Indonesia. Jakarta: Ardarizya Jaya. 
Burhanuddin (2002), Analisis Administrasi Manajemen dan Kepemimpinan Pendidikan. Jakarta: Bumi Aksara.

Davis, Keith \& John W Newstrom (2000), Perilaku Organisasi Jilid 1, Alih Bahasa Agus Dharma, Jakarta, Erlangga.

Edina Dóci, Jeroen Stouten, dan Joeri Hofmans (2015), The cognitive-behavioral system of leadership: cognitive antecedents of active and passive leadership behaviors, Front Psychol. 2015; 6: 1344. Published online 2015

Sep

7. doi: $10.3389 /$ fpsyg.2015.01344.

Kartini Kartono (2002), Pemimpin dan Kepemimpinan., Edisi Baru, PT. Raja Grafindo Persada. Bandung.
Owens, R.G. (1991). Organizational Behavior in Education. Boston: Allyn and Bacon.

Ridwan El Hariri, (2011), Pengaruh Perilaku Kepemimpinan Terhadap Kinerja Layanan Akademik Pegawai di Universitas Pendidikan Indonesia, Manajerial, Vol. 10 No. 19, Juli 2011, hal. 9 halaman.

Robbins, Stephen P. (2002). Prinsip-prinsip Perilaku Organisasi. Jakarta: Erlangga.

Stonner, E \& Freeman, D.G. (2004). Manajemen. Jakarta: Prenhallindo.

Yukl, Gary A. (1989). Leadership in Organizations. 2nd Ed.New Jersey: Prentice-Hall International, Inc. 